\title{
ПІДВИЩЕННЯ ЕКСПЛУАТАЦІЙНИХ ХАРАКТЕРИСТИК ЕНЕРГОАКТИВНИХ ОГОРОДЖЕНЬ: КОНСТРУКТИВНІ ОСОБЛИВОСТІ ЗАСТОСУВАННЯ ТЕЛЕСКОПІЧНИХ МЕХАНІЗМІВ
}

\author{
В.І. Свірса, студент, Л.В. Накашидзе, д-р техн. наук, ст. наук. співроб., директор НДІ енергетики
}

Дніпровський національний університет імені Олеся Гончара,

49000, проспект Гагаріна, 72, Дніпро, Дніпропетровська область, Україна.

Одним з основних завдань енергетики на сьогоднішній день є вирішення проблеми зменшення енергоспоживання 6 житловому та промисловому секторах. Від результатів вирішення иієї проблеми безпосередньо залежить економічна й енергетична незалежність споживачів, особливо в умовах обмеженого доступу до енергоресурсів. Оптимальний шлях до вирішення проблеми енергоспоживання передбачає впровадження енергоактивних технологій. У статті розглянуто переваги та недоліки ряду конструкцій енергоактивних огороджень та визначено напрям їх вдосконалення. Зазначені особливості виконання енергоактивних огороджень окреслені використанням конструкиії з поворотним механізмом, статичної конструкції з нерухомими елементами, комплексної та роздільної конструкиій, а також конструкції зі змінними розмірами. Зроблено аналіз запропонованих технічних рімень, а також проведено порівняння ефективності їх функиіонування в різних умовах з урахуванням потреб та вимог споживача. Визначено метод вдосконалення енергоактивних огороджень, що дає змогу формувати конструкції пристрою, які спроможні за різних експлуатаційних умов показати високі технічні та енергетичні характеристики. У роботі представлено інноваційну динамічну систему, конструкиія якої містить механізм фронтального телескопічного переміщення. Представлено варіанти конструктивного виконання енергоактивних огороджень, щьо трунтуються на зазначеному принципі. Ефективність експлуатаційних характеристик розглянутих пристроїв підтверджено розрахунками, які виконані на базі програмного комплексу SolidWorks. Впровадження розроблених конструкцій енергоактивних огороджень сприятиме вирішенню проблеми зменшення енергетичної залежності споживачів промислового, аграрного та житлово-комунального секторів. У статті означено напрями подальшого розвитку та вдосконалення конструкцій енергоактивних огороджень та показана дочільність подальших досліджень особливостей їх функиіонування. Бібл. 15, табл. 1, рис. 5.

Ключові слова: енергозбереження споруд, енергоактивні огородження, статична система, модульна конструкція, показник надійності, телескопічний механізм, проєкційна площчина, вентиляційна система, сонячний цикл.

\section{THE USE OF TELESCOPIC MECHANISMS AS A DIRECTION FOR THE DEVELOPMENT OF ENERGY-ACTIVE FENCING TECHNOLOGY}

\author{
V. Svirsa, student, L. Nakashydze, $\mathrm{PhD}$ in technical sciences, senior researcher, director of the research institute of energy \\ Dnipro National University named after Oles Honchar, \\ 49000, 72, Gagarina avenue, Dnipro, Dnipropetrovsk region, Ukraine.
}

One of the main tasks of energy today is to solve the problem of energy consumption in the residential and industrial sectors. The economic situation and energy independence of consumers directly depend on the results of solving this problem, especially in conditions of limited access to energy resources. In this work, the best way to solve the problem of energy consumption involves the introduction of energy-active technologies. The article lists the advantages and disadvantages of different methods of construction of energy-efficient fencings and identifies the direction of their improvement. The considered methods of execution of energy-active fencings include use of a design with the rotary mechanism, a static design with fixed elements, complex, separate, and also a design with the variable sizes. The theoretical analysis of the considered technical decisions is carried out, and also the comparison of efficiency of functioning in various conditions, taking into account needs and requirements of the consumer is carried out. The method of improvement of technology of energy-active fencings which leads to formation of a design of the device which are capable to show high technical and power characteristics under various operating conditions is defined. The paper formulates the idea of an innovative dynamic system, which is based on the mechanism of frontal telescopic movement, as well as a variant of energy-active fencings, which is based on this principle. The results are confirmed by calculations performed on the basis of the SolidWorks 
software package. The introduction of the developed designs of energy-efficient fencings will help solve the problem of reducing the energy dependence of consumers in the industrial, agricultural and housing and communal sectors. The article identifies areas for further development and improvement of structures of energy-active fencings and shows the need for research on the features of their operation. Ref. 15, tab. 1, fig. 5.

Keywords: energy saving of constructions, energy active protections, static system, modular design, reliability indicator, telescopic mechanism, projection plane, ventilation systems, solar cycle.

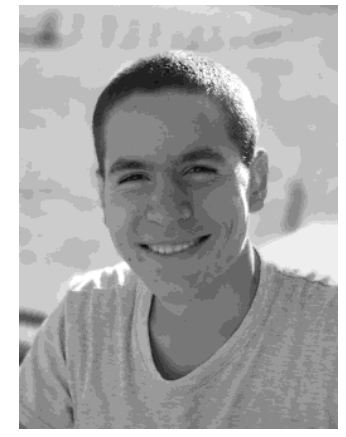

B.I. Coipca V. Svirsa

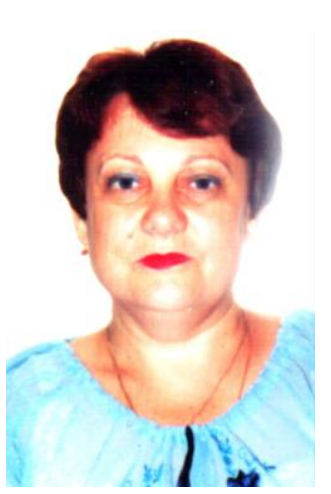

Л.В. Накашидзе L. Nakashidze
Відомості про автора: студент

Дніпровського національного університету імені Олеся Гончара

Освіта: середня

Наукова діяльність: відновлювані джерела енергії, енергозабезпечення

Публікації: 10 наукових доповідей

ORCID: 0000-0003-0012-3599

Контакти: тел.: +38(096)3737190

e-mail: muranos1000@gmail.com

Відомості про автора: д-р техн. наук, ст. наук. співроб., директор НДІ енергетики Дніпровського національного університету імені Олеся Гочара

Освіта: Дніпропетровський хімикотехнологічний інститут, факультет технологія неорганічних речовин, спеціальність: технологія неорганічних речовин (1985)

Наукова сфера: відновлювані джерела енергіï

Публікації: більше 150 наукових робіт

ORCID: 0000-0003-3990-6718

Контакти: тел.: +38(097)3635270

e-mail: foton_dnu@ukr.net
Author information: Oles Honchar Dnipro

National University student

Education: secondary education

Reasearch area: the renewable and alternative energy sources, energy providing

Publications: 10 scientific works

ORCID: 0000-0003-0012-3599

Contacts: tel.: $+38(096) 3737190$

e-mail: muranos1000@gmail.com

Author information: Ph.D., seniorres. Science, director of the Energy Research Institute Oles Honchar Dnipro National University

Education: Dnepropetrovsk Institute of Chemical Technology, Faculty of Technology of inorganic compounds, specialty technology of inorganic compounds (1985)

Research area: the renewable and alternative energy sources

Publications: more than 150 scientific works

ORCID: 0000-0003-3990-6718

Contacts: tel.: $+38(097) 3635270$

e-mail: foton_dnu@ukr.net
Вступ: Під час проєктування житлових будинків та інших споруд важливим є вирішення питання сталого енергозабезпечення за умови ефективного використання енергетичних ресурсів [5]. Підвищенню енергоефективності сприяє захист огороджувальних конструкцій споруди від тепловтрат і негативного впливу довкілля. Відомі пасивний та активний методи теплового захисту будівель [6]. Пасивний метод передбачає використання в спорудах шарів матеріалу, що має низький коефіцієнт теплопровідності [1]. Активний метод полягає в передачі теплового потоку, що надходить, до теплоносія з подальшим його виведенням за межі захищуваного об'єкта [7]. Для реалізації такого підходу запропоновано використання енергоактивних огороджень. Впровадження енергоактивних огороджень дає змогу вирішити ряд завдань, пов'язаних 3 теплозбереженням та підвищенням енергоефективності, а також передбачає позитивний вплив на архітектурний вигляд споруди [15]. Проте енергоактивні огородження не позбавлені недоліків [2]. Основним 3 них $\epsilon$ необхідність оптимізації конструкції енергоактивних огороджень при використанні на певному об'єкті, яка виникає через низьку модульність та особливості технології виготовлення як самої конструкції, так і всіх іï складових [7].

Постановка завдання. Метою даної роботи $\epsilon$ окреслення методів удосконалення конструкції енергоактивних огороджень шляхом 
раціоналізації елементів конструкції та визначення супутнього впливу на технічні та експлуатаційні чинники.

Основними завданнями є:

- аналіз систем регулювання сонячного потоку в енергоактивних огородженнях (з огляду на їх технічні та експлуатаційні характеристики);

- формування моделі енергоактивних огороджень 3 телескопічним механізмом (3 урахуванням розрахункових фізико-технічних характеристик).

Виклад

\section{основного}

матеріалу. Енергоактивне огородження - це багатофункціональна будівельна конструкція, яка призначена для одночасного виконання функцій поглинання, перетворення, перерозподілу та акумулювання енергії випромінювання Сонця [3]. Конструкція обмежовує споруду, забезпечуючи захист приміщень від небажаного впливу кліматичних $\mathrm{i}$ техногенних чинників навколишнього середовища та одночасно $\epsilon$ невід'ємним активним елементом системи енергозабезпечення [15]. Енергоактивне огородження складається 3 ряду функціональних елементів [2]. У процесі розробки енергоактивного огородження актуальним $\epsilon$ питання вибору конструктивних елементів, матеріалів з урахуванням впливу їх властивостей на ефективність всієї конструкції [1]. Усі елементи пристрою є невід'ємними складовими цілісної системи, в якій кожен 3 них виконує певну функцію (табл. 1) [10].

Таблиця 1. Перелік основних складових елементів конструкції енергоактивного огородження

Table 1. List of the main constituent elements of the structure of energy-active fences

\begin{tabular}{|l|l|}
\hline \multicolumn{1}{|c|}{ Складовий елемент пристрою } & \multicolumn{1}{|c|}{ Коментар } \\
\hline $\begin{array}{l}\text { Базова основа з будівельного } \\
\text { матеріалу (наприклад, базовий } \\
\text { елемент конструкції споруди), } \\
\text { на яку кріпляться інші елементи }\end{array}$ & $\begin{array}{l}\text { Вирішальними характеристиками для цього елемента є } \\
\text { довговічність, висока екологічність та низька теплопровідність. } \\
\text { Запропонований авторами матеріал: газобетон. }\end{array}$ \\
\hline $\begin{array}{l}\text { Шар теплоізоляції з матеріалу } \\
\text { пористої або стільникової } \\
\text { структури }\end{array}$ & $\begin{array}{l}\text { Забезпечує підвищення показників термічного опору елемента } 3 \\
\text { будівельного матеріалу. Матеріал повинен мати невелику вагу, } \\
\text { бути практичним і доступним. Рекомендований авторами } \\
\text { матеріал: ековата [11]. Вона випереджає базові типи утеплень за } \\
\text { рядом якостей, таких як стійкість до горіння та екологічність. }\end{array}$ \\
\hline $\begin{array}{l}\text { Вологонепроникний } \\
\text { енерговідбивальний шар }\end{array}$ & $\begin{array}{l}\text { Забезпечує умови, які перешкоджають проникненню атмосферної } \\
\text { вологи всередину конструкції, а також зупиняє залишки розсіяної } \\
\text { сонячної радіації [11]. 3 цим завданням здатні впоратися } \\
\text { більшість типів паровологоізоляційних мембран і } \\
\text { сонцевідбивальних покриттів. }\end{array}$ \\
\hline $\begin{array}{l}\text { Теплосприймальні елементи, } \\
\text { виконані у формі жалюзі }\end{array}$ & $\begin{array}{l}\text { Поглинальна спроможність матеріалу в оптичному діапазоні } \\
\text { сонячного випромінювання повинна бути достатньо високою. }\end{array}$ \\
Авторами встановлено, що фарбована алюмінієва пластина \\
матиме достатні теплопоглинальні властивості.
\end{tabular}

Завдяки тому що енергоактивні огородження $є$ багатошаровими конструкціями, створюються умови для ефективної підтримки енергетичного балансу між надходженням i втратою енергії сонячного випромінювання та енергії довкілля [3]. Призначенням енергоактивних огороджень є захист внутрішніх приміщень будівель від перегріву або переохолодження i, крім цього, регульований i деталізований розподіл енергії між зовнішніми та внутрішніми поверхнями приміщень [2]. Проте у певних умовах експлуатації продуктивність 
енергоактивних огороджень може зменшуватися. Під час організації системи енергозбереження будівель впровадження енергоактивних огороджень супроводжується низкою проблем, пов'язаних насамперед з вартістю та габаритними розмірами конструкції. Такі питання можливо вирішити, наприклад, за допомогою поділу рівнів огородження та спрощення системи контролю [4]. Енергоактивні огородження мають безліч переваг i великий потенціал для вирішення проблеми енергоспоживання, але є недоліки які

зі свого боку значно уповільнюють широкомасштабне впровадження цих конструкцій [8]. Для окреслення цих недоліків проаналізовано зміну такого показника, як модульність (один з показників, що характеризує технологічність конструкції), на прикладі конструкції енергоактивного огородження 3 роздільними елементами. Для цього конструктивні елементи енергоактивного огородження умовно розділено на такі категорії, як зовнішні та внутрішні, тобто ті, що взаємодіють 3 навколишнім середовищем, i ті, що не взаємодіють [9]. До зовнішніх належать світлопрозора ізоляція, масив теплосприймальних елементів та вологонепроникне енерговідбивальне покриття [12], а до внутрішніх - стіна (дах) споруди 3 базового матеріалу та прошарок теплоізоляції. Усі елементи поєднані між собою і складають сталу конструкцію, яка є частиною будівлі та має відносно низьку модульність в умовах монтажних робіт [10].

На рис. 1. зображена модульна конструкція, що складається лише 3 тих елементів енергоактивного огородження, які підлягають впливу навколишнього середовища. Вона виконана 3 ударостійкого скла. Також до складу конструкції входить ряд динамічних або статичних металевих пластин, шар вологоізоляції, пластиковий каркас, призначений для закріплення усієї конструкції, та стіни (даху) будівлі. Довжина i ширина теплосприймальних елементів має бути виконана відповідно до потреб споживача, але має бути не більше ніж $3 \times 6$ м, інакше це позначиться на технологічності монтажу системи [11]. Простір для повітряних каналів має зберігати зазори 3 певними розмірами 3 обох боків від пластин [12]. Каркас 3 високоміцного пластику призначений для фіксації усієї конструкції $[5,7]$. Для поєднання між собою окремих блоків у вентиляційну мережу будова каркасу передбачає наявність кріпильних рамок на протилежних його кінцях вздовж напрямку руху теплоносія [8]. Декілька таких вертикальних блоків можна направити до спільної повітряної камери, 3 якої також теплоносій буде надходити до теплоакумулювальної системи.

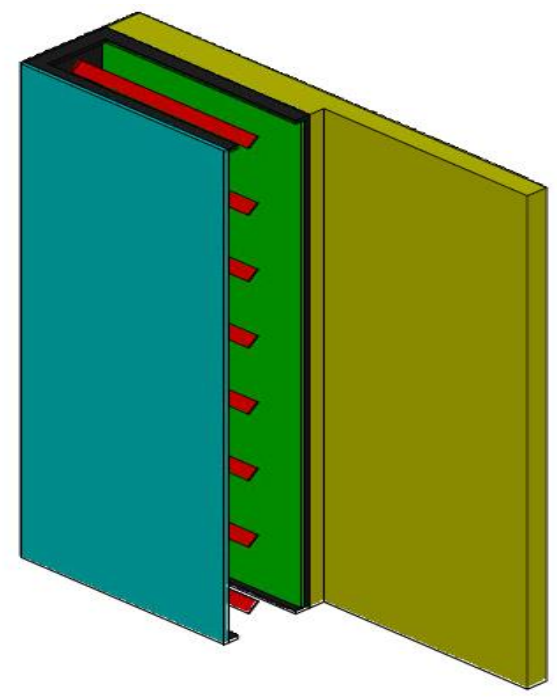

Рис. 1. Структурна схема модульної конструкції енергоактивного огородження

Fig. 1. The structure of the modular design 
Отже, одним 3 варіантів вдосконалення енергоактивних огороджень $є$ використання спрощеної системи сприймання сонячної енергії та регулювання енергетичного потоку. Вона базується на системі віддзеркалювання променів [6]. Розділення елементів між собою дозволяє використовувати зовнішній периметр споруди для ефективного збору сонячної енергії, або статичного регулювання потоку. При цьому використовуються перенаправлені сонячні промені. Така конструкція дозволяє розділяти елементи огородження на дві самостійні підсистеми, що значно підвищує модульність конструкції [4]. Пристрій, що має таку конструкцію, технологічний при створенні та використанні, оскільки передбачає почергову організацію функціонування системи [9].

Подальший аналіз проведено для модульної технології збору сонячної енергії на основі компактного розташування та роздільності складових конструкцій (далі роздільна концепція). Перевагою такої конструкції є іiі менша матеріалоємність. Також передбачається зменшення функціональної залежності одного блоку системи від інших i складових. Недоліком роздільної концепції $є$ ускладнення монтажу динамічних систем 3 поворотними елементами. Роздільна концепція енергоактивних огороджень може отримати перспективи для удосконалення 3 погляду модульності конструкції лише у разі спрощення теплосприймальної системи, наприклад виключення поворотного механізму або впровадження інших типів рухомих елементів.

В енергоактивних огородженнях поворотний механізм забезпечує розподіл поглиненого та розсіяного сонячного випромінювання [2]. Завдяки зміні кута нахилу теплосприймальних пластин змінюється кут надходження сонячних променів [5]. У відкритому положенні, коли пластини направлені паралельно сонячним променям, вони поглинають найменшу можливу кількість тепла, a y положенні, коли пластини направлені перпендикулярно сонячним променям, найбільшу. Коли кут нахилу має проміжне положення між перпендикулярним та паралельним напрямом сонячного потоку, частина променів перенаправляється на внутрішню поверхню сусідніх пластин. Така конструкція дозволяє регулювати кількість отриманого тепла, але потребує додаткових поворотних пристроїв [3].

Для того щоб полегшити створення, реалізацію та обслуговування активної системи, пропонується вдосконалити конструкції поворотного механізму. Зменшення ступеня контролю за регулюванням потоку та використання простіших конструкторських засобів позитивно вплине на модульність i доступність технології. Окреслено, що поворотний механізм завдяки конструктивним особливостям негативно впливає на величину показника модульності конструкції.

Було проаналізовано варіант 3 наявністю рухомого механізму, в основі якого лежить ефект накладення проєкції однієї поверхні на іншу. Така конструкція дозволяє варіювати функціональні можливості поверхні панелі. Це дає змогу вдатися до способів створення енергоактивних огороджень, в основі яких лежить динамічна система руху шарів термочутливих елементів (виключається використання статичної конструкції або обертального механізму). Принцип розташування пластин полягає в тому, що кілька однакових рядів пластин, розташованих паралельно, повинні проєкційно складати одну загальну функціональну площину, перебуваючи при цьому на різній глибині у просторі. В міру переміщення пластин змінюватиметься площа проєкційної площини, що приведе до зміни кількості поглиненої або втраченої теплової енергії. Такий самий ефект буде в разі переміщення рядів пластин по нормалі до панелі. Ступінь зміни проєкційної площини залежить від кута напрямку проєкції (тобто кута нахилу до джерела світла). Отже, збільшити кількість енергії, що поглинається, можна, заздалегідь розташувавши пластини по напрямку до джерела світла. Під час руху пластин можна досягти такого їх взаємного розташування, при якому 
проєкційна площина буде максимальною або мінімальною. Можливі також проміжні положення. Здійснити кріплення пластин (зокрема в рядах) можна за допомогою телескопічних механізмів, встановлених вздовж руху рядів пластин. При цьому кожна пластина бере участь у пересуванні. Змінювати положення пластин можна за допомогою додаткових кріплень або важелів.

Іншим варіантом телескопічного симетричного розсування $€$ телескопічне розсування 3 рухом у сторони. У цьому разі регулювання потоку відбувається завдяки приведенню у рух масиву теплосприймальних пластин. При цьому відбувається зміна загальної теплопоглинальної площини, i вона $є$ сумою теплопоглинальних площин усіх пластин. Кількість пластин, що беруть участь у процесі теплообміну, може змінюватися. Телескопічні кріплення встановлюються вздовж єдиного масиву пластин у напрямку їх розсування.

У представлених способах розташування рухомих елементів 3 використанням телескопічних шарів $\epsilon$ кілька суттєвих відмінностей. Розташування за напрямком руху в сторони, на відміну від фронтального, передбачає менш ефективне використання положення у просторі навколо одного функціонального блоку. Сукупності пластин, розташованих за такою схемою, мають недостатні аеродинамічні властивості, а також потребують більшої кількості енергії на механічні трансформації. Натомість спосіб розташування 3 фронтальним напрямком руху пластин позбавлений таких недоліків i $€$ доцільним в конструкції енергоактивних огороджень.

Для проведення розрахунку технікофункціональних особливостей моделі енергоактивного огородження прийнято припущення відносно розмірів деталей та вузлів, що входять до складу пристрою та беруть участь у конвекції повітряним потоком. Прийнято, що до одного функціонального блоку входять такі частини: масив теплосприймальних елементів 3 нефарбованого алюмінію, телескопічні кріплення та пластиковий каркас 3 квадратними отворами для протікання теплоносія. Масив теплосприймальних елементів складається 332 пластин, по чотири в одному горизонтальному ряді. При формуванні функціонального блоку між пластинами та внутрішніми стінками блока необхідно передбачити технологічні зазори, які забезпечують запобігання контакту між поверхнями пластин при механічних перетвореннях. 3 урахуванням прийнятих допущень проведено розрахунок моделі енергоактивного огородження 3 фронтальним напрямом руху пластин. Для розрахунку моделі була прийнята умова про те, що температура усіх пластин залишається постійною та відповідає температурі, яка $\epsilon$ сталою при максимальній сонячній активності протягом доби [13]. Відомо, що сталою температурою є така температура, за якої кількість отриманої тілом сонячної енергії дорівнює кількості втраченої тілом енергії на теплопередачу конвекцією та радіаційне випромінювання в певний момент часу [14]. Величина сталої температури залежить від матеріалу тіла, площі його поверхні, що бере участь у конвективному теплообміні, кількості отриманого сонячного випромінювання, а також температури та швидкості повітря навколо [14]. Тіло досягає сталої температури у той момент часу, коли секундний температурний приріст прямує до нуля [13].

Секундний температурний приріст можна визначити за формулою:

$$
d T=\frac{Q}{c \cdot m},
$$

де Q - приріст кількості теплоти за секунду, Дж; $\mathrm{C}$ - питома теплоємність речовини, Дж/кг · град; M - маса тіла, кг.

Приріст кількості теплоти визначається в такий спосіб:

$$
Q=Q_{\text {надх }}-Q_{\text {конв }}+Q_{\text {випр }},
$$

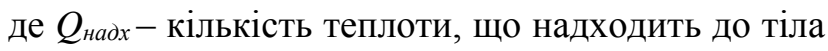
у вигляді сонячної енергії, Дж; $Q_{\text {конв }}-$ кількість теплоти, яку втрачає тіло під час конвективного теплообміну, Дж; $Q_{\text {випр }}$ - кількість теплоти, яку втрачає тіло на радіаційне випромінювання, Дж. 


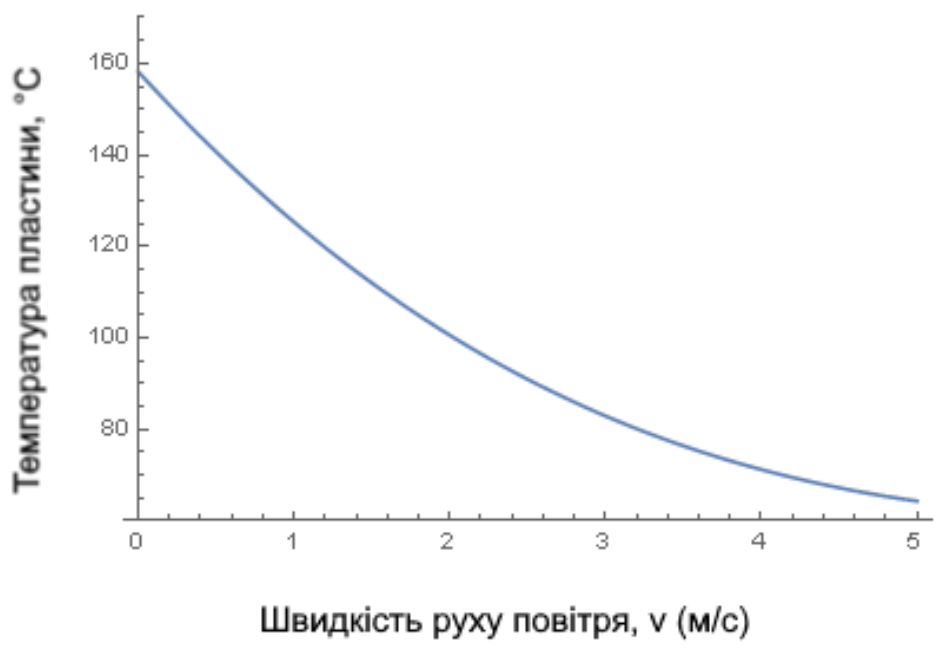

Рис. 2. Залежність температури пластини від швидкості руху повітря

Fig. 2. Dependence of the plate temperature on the air velocity

На рис. 2 зображена графічна залежність сталої температури пластини від швидкості руху повітря в межах від 0,2 до $5 \mathrm{~m} / \mathrm{c}$ при середній кількості сонячній енергії, що надходить під час теплого періоду року. Встановлено, що в холодний період року стала температура пластини та всі інші температурні показники зменшуються в середньому на 3-4 градуси за лінійним законом.

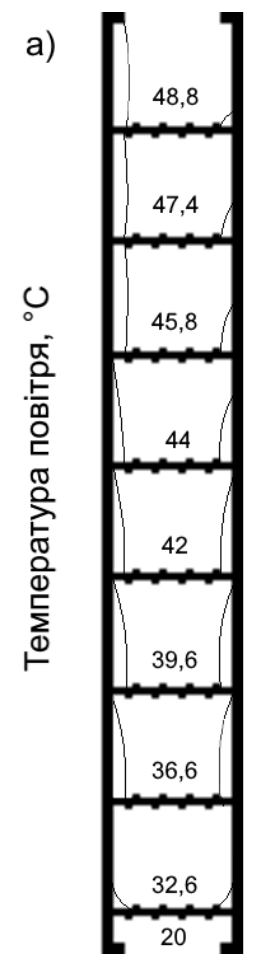

б)

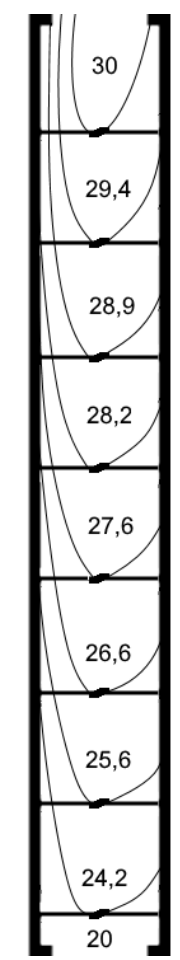

Рис. 3. Динаміка зміни температур повітряного потоку в двох крайніх положеннях пристрою: a) температури повітря у розкритій конструкції; б) температури повітря у закритій конструкції

Fig 3. Dynamics of air temperature changes in the two extreme positions of the device: a) air temperature in a opened structure; b) air temperature in a closed structure 
На рис. 3 зображена динаміка зміни температур повітряного потоку в двох крайніх положеннях пристрою. У першому положенні між пластинами зберігається максимальна відстань, або при переміщені пластин на повну амплітуду руху телескопічної конструкції. У другому положенні між пластинами зберігається мінімальна відстань. Температурне поле у вигляді сукупності ізотерм, зображене на рис. 3, є спрощеним та несуттєво відрізняється від реального. Розрахунок теплових потоків для різних станів пристрою та за різних початкових умов був проведений за допомогою програмного комплексу SolidWorks. Задано припущення, що в закритому положенні конструкції, коли пластини розташовані поряд, температурне поле буде близьким до такого, яке створюється, коли в ряду одна пластина замість чотирьох. При збільшенні числа пластин в одному ряду та максимальній відстані між ними зростає і середня температура повітря на виході 3 блоку. Результати розрахунків показують, що рух потоку не спричиняє утворення турбулентних завихрень та зміну характеру потоку при заданій швидкості руху повітря.

На рис. 4 зображена залежність температури повітря на виході з функціонального блоку від рівня відкриття масиву пластин (відстань між пластинами). Відстань між пластинами змінюється від мінімальної до відстані у 28,4 мм. Температура повітря на виході 3 функціонального блоку змінюється від 30 до $48,8^{\circ} \mathrm{C}$ залежно від відстані між пластинами. Температура пластин в одному ряду також відрізняється: перша пластина має сталу температуру, а температури інших трьох пластин змінюються залежно від відстані між ними. Така зміна $\epsilon$ наслідком зменшення площі теплопоглинальної поверхні кожної з пластин, окрім першої; це своєю чергою впливає на величину сонячної енергії, що надходить до системи. Варто зазначити, що характер залежності температур $\epsilon$ тільки близьким до лінійного. Це пов'язано з великою різницею між температурами лицьової пластини та інших пластин у ряду.

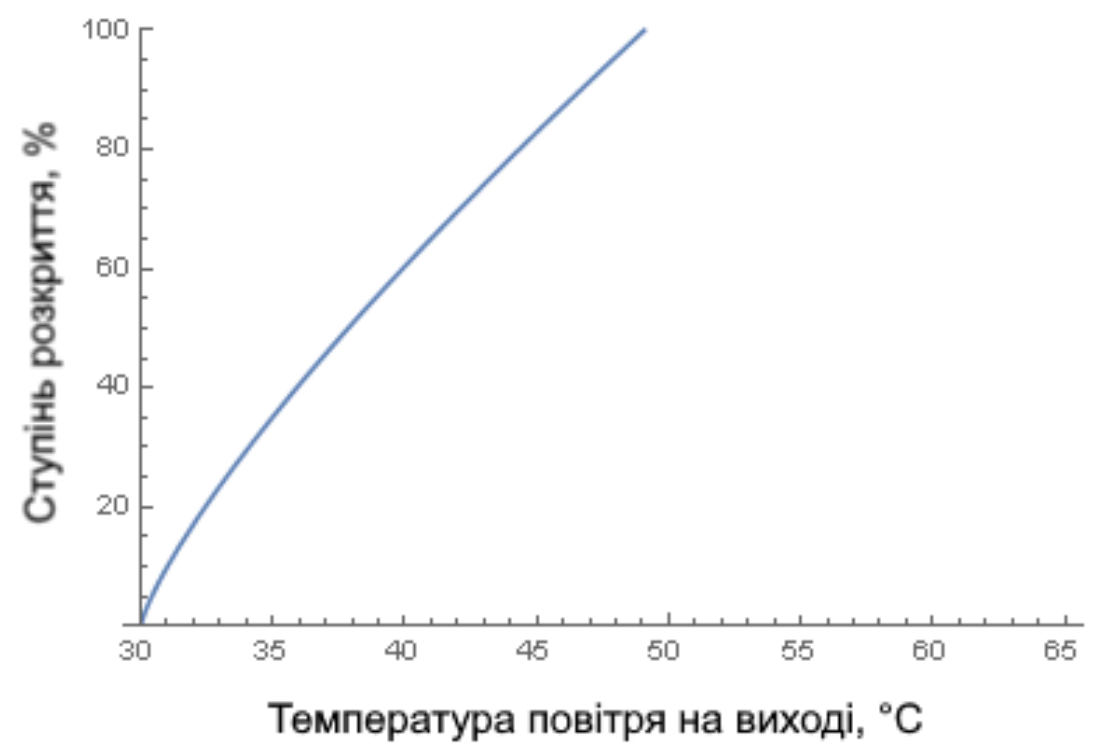

Рис. 4. Залежність температури повітря на виході з блоку від ступеня розкриття секцій пластин

Fig. 4. Dependence of the outlet air temperature on the degree of opening of the plate sections 
Масив функціональних блоків, поєднаних між собою, утворює вентиляційний канал, який призначений нормалізувати повітряний потік i запобігти проходженню холодних течій вздовж стінок блоку. Проведено розрахунок вентиляційної системи, що складається 3 трьох функціональних блоків. На рис. 5 зображена залежність середньої температури повітря у вентиляційній системі від числа функціональних блоків. Така залежність також справедлива для визначення середньої температури повітря в межах одного функціонального блоку в залежності від глибини проходження теплового потоку вздовж функціонального блоку. На рис. 5 проведено порівняння двох залежностей: перша дійсна для блоків з закритими секціями пластин, а друга - з відкритими секціями.

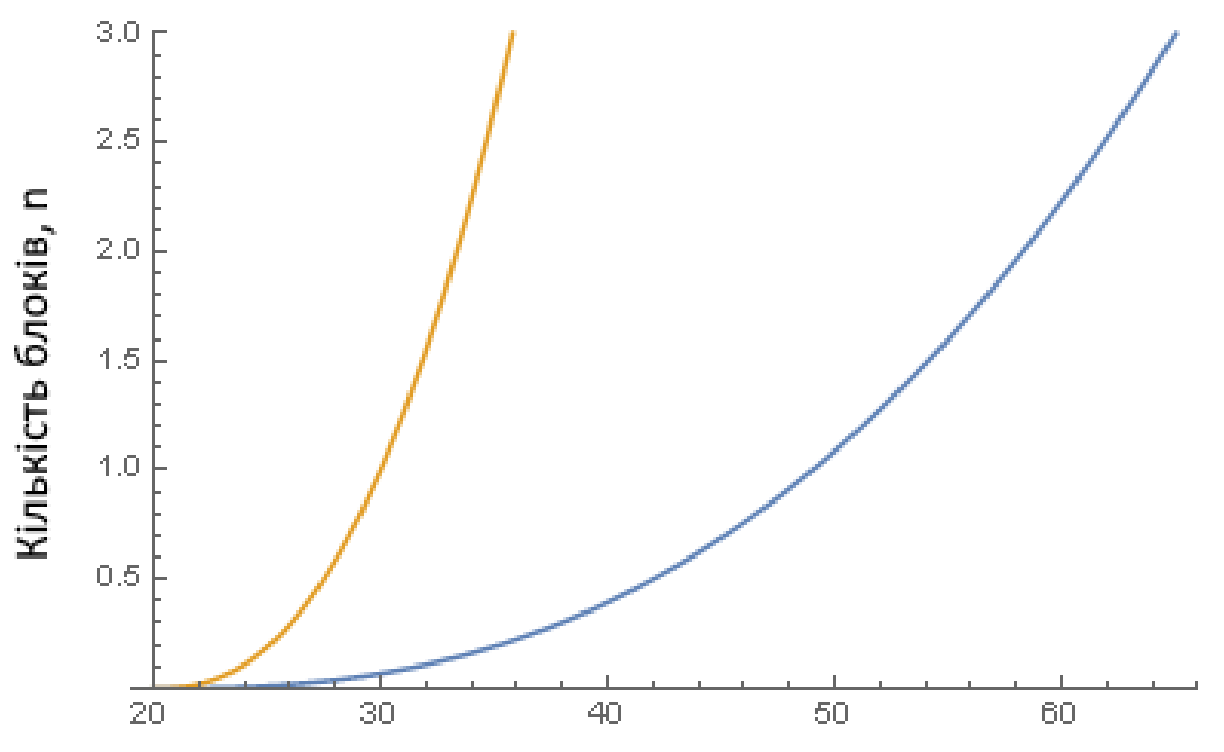

Температура повітря у закритих та відкритих блоках, ${ }^{\circ} \mathrm{C}$

Рис. 5. Залежність температури повітря від кількості блоків для закритих та відкритих секцій пластин

Fig. 5. Dependence of air temperature on the number of blocks for closed and open sections

Попередній розрахунок, проведений щодо енергоактивних огороджень із фронтальним телескопічним регулюванням при певних геометричних та фізичних параметрах конструкції, дозволив окреслити відомості 3 ефективності функціонування установки. Отримані результати свідчать про те, що заданий порядок розміщення теплосприймальних елементів позитивно впливає одразу на ряд технологічних властивостей:

- раціональне використання зайнятої поверхні будівлі;

- кращі аеродинамічні й теплопродуктивні характеристики.
Площа поверхні, на яку монтуються функціональні блоки, що відповідають рекомендованим розмірним пропорціям, учетверо менше, ніж передбачено іншими конструктивними рішеннями. Функціональні блоки, що мають розглянуту конфігурацію пластин, дають змогу отримати більш високі температури повітря на виході до системи енергогенерування. У разі збільшення числа теплосприймальних елементів в одному ряду та при максимальній відстані між ними, зростає i середня температура повітря на виході з блоку. Окрім цього, енергоактивні огородження, для яких проводився розрахунок, дозволяють створити необхідну конфігурацію пластин. Вся 
перелічена сукупність чинників вказує на позитивні технологічні й економічні переваги пристрою.

\section{Висновки: Пропонується модифікація} енергоактивних огороджень 3 динамічною системою, в основі якої лежить фронтальний телескопічний рух пластин та їх масивів, що використовує роздільні елементи конструкції. В цій конструкції також використано ефект віддзеркалення та перенаправлення сонячних променів. Устаткування такого типу доцільне для використання в активних системах енергозабезпечення будівель і споруд будь-якої apхітектури. Телескопічні енергоактивні огородження мають досить просту конструкцію, тому не вимагають надмірної уваги під час обслуговування. 3 цієї ж причини телескопічні енергоактивні огородження виявляються дешевшими у виробництві, ніж інші типи енергоактивних огороджень. Застосування цієї простої, але високоефективної технології дає можливість вийти на ринок енергоощадних технологій.

1. Аляутдинова Ю.А. Использование солнечной энергии для снижения теплопотерь здания. Вестник БГТУ им. В. Г. Шухова. 2018. № 11. С. 47-52.

2. Басок Б.И. $\quad m a$ ін. Теплофизика влияния солнечного излучения на здания. Киев. Видавництво «Наукова думка» НАН України. 2016. 224 с.

3. Габрінець В.О. та ін. Дослідження особливостей побудови енергоактивних огороджень як елементів систем енергозабезпечення. Проблемы высокотемпературной техники: зб. наук. праць. Дніпро. ДНУ імені Олеся Гончара 2011. C. $7-14$.

4. Габрінець В.О., Накашидзе Л.В., Сокол Г.І. та ін. Формування схемних рішень системи акліматизації споруд в робочому середовищі альтернативних джерел енергії: монографія. Дніпро. ДНУ імені Олеся Гончара. ТОВ «Акцент ПП.». 2016. 152 с.

5. Габрінеиь В.О., Накашидзе Л.В., Марков В.Л. та $i н$. Особливості побудови енергоактивних огороджень у складі систем енергозабезпечення на основі ВДЕ. Відновлювана енергетика. К. 2010. № 3. С. 31-34.

6. Накашидзе Л.В. Основні вимоги до енергоактивних огороджень. Відновлювана енергетика. К. 2013. № 1. C. 48-51.

7. Накашидзе Л.В. Особливості вибору конструкції перетворювачів енергії сонячного випромінювання в системах енергозабезпечення споруд: монографія. Дніпро. ДНУ імені Олеся Гончара. ТОВ «Акцент ПП». 2018. 119 с.

8. Накашидзе Л.В. Теплотехнічні особливості побудови енергоактивного огородження. Відновлювана енергетика. К. 2013. № 2. С. 49-53.

9. Накашидзе Л.В. Улучшение эксплуатационных характеристик сооружений при использовании энергии альтернативних источников. Международный научный журнал «Альтернативная енергетика и экология». 2014. № 23. C. 84-89.

10. Накашидзе Л.В., Габринеиь Л.В. Формирование состава системы энергообеспечения, использующей энергию ехнологи вних источников. Строительство, материаловедение, машиностроение: сб. научн. трудов. Серія: Инновационные технологи жизненного цикла объектов жилищно-гражданского, промышленного и транспортного назначения ГВУЗ «Приднепр. Гос. Академия стр-ва и архитектуры». Дніпро. 2016. № 87. С. 84-91.

11. Габринець В.О., Зарівняк Г.І., Митрохов С.О., Накашидзе Л.В. Патент на корисну модель UA61489. Україна МПК F24G 2/50 . E04B 1/76 Енергоактивне огородження. Україна. № u201014333. Заявл. 30.11.2010. Видача .патенту 25.07.2011. бюл. № 14.

12. Накашидзе Л.В., Шевченко М.В., Габрінеиь В.О. Патент на корисну модель UA109070. Україна. МПК F24G 2/50. Е04B 1/76 Енергоактивне огородження. Опубл. 01.08.2016. Бюл. № 15. заявл. 16.02.2016.

13. Протасович А.М. Расчет температурного поля многослойных ограждающих конструкций с теплопроводными включениями методом конечных элементов. Энергоэфффективсность Минск. 2013. № 10. C. $16-20$.

14. Упрощенная модель солнечного нагрева поверхностей. Bogdan's blog. 2014. [Електронний ресурс]. URL: http://2nature.me/node/9321.

15. Фокин В.M. та ін. Основы энергосбережения в вопросах теплообмена. М. Издательство «Машиностроение-1». 2005. 192 с.

\section{REFERENCES}

1. Alyautdinova Y.A. Ispolzovanie solnechnoj energii dlya snizheniya teplopoter zdaniya [Using solar energy to reduce heat loss in a building]. Vestnik BGTU n.a. V.G. Shukhov. 2018. № 11. Pp. 47-52. [in Russian]

2. Basok B.I., Nakorcheskij A.I. Teplofizika vliyaniya solnechnogo izlucheniya na zdaniya. [Thermal physics of the influence of solar radiation on buildings]. Kyiv. publ. «Naukova dumka» NAS of Ukraine. 2016. 224 p. [in Russian].

3. Gabrinec V.O., Markov V.L. and others. Doslidzhennya osoblivostej pobudovi energoaktivnih ogorodzhen yak elementiv sistem energozabezpechennya. [Research of peculiarities of construction of energy-active fencings as elements of energy supply systems]. Problemy 
vysokotemperaturnoj tehniki: collection of scientific papers Dnipro. DNU n.a. Oles Honchar. 2011. Pp. 7-14. [in Ukrainian].

4. Garbinec V.O., Nakashidze L.V., Sokol G.I. and others. Formuvannya shemnih rishen sistemi aklimatizaciyi sporud $\mathrm{v}$ robochomu seredovishi alternativnih dzherel energiyi: monografiya. [Formation of circuit solutions of the system of acclimatization of buildings in the working environment of alternative energy sources: a monograph]. Dnipro. DNU n.a. Oles Honchar. Ltd. «Akcent PP». 2016. 152 p. [in Ukrainian].

5. Gabrinec V.O., Nakashidze L.V., Markov V.L. and others. Osoblivosti pobudovi energoaktivnih ogorodzhen $\mathrm{u}$ skladi sistem energozabezpechennya na osnovi VDE. [Features of construction of energy-active fencings as a part of power supply systems on the basis of RES]. Vidnovlyuvana energetika. 2010. No. 3. Pp. 31-34. [in Ukrainian].

6. Nakashidze L.V. Osnovni vimogi do energoaktivnih ogorodzhen. [Basic requirements for energy-efficient fences]. Vidnovlyuvana energetika. 2013. No. 1. Pp. 48-51. [in Ukrainian].

7. Nakashidze L. V. Osoblivosti viboru konstrukciyi peretvoryuvachiv energiyi sonyachnogo viprominyuvannya $\mathrm{v}$ sistemah energozabezpechennya sporud: monografiya. [Features of a choice of a design of converters of energy of solar radiation in systems of power supply of constructions: a monograph]. Dnipro. DNU n.a. Oles Honchar. Ltd. «Akcent PP». 2018. 119 p. [in Ukrainian].

8. Nakashidze L.V. Teplotehnichni osoblivosti pobudovi energoaktivnogo ogorodzhennya. [Thermotechnical features of construction of an energy-active fencing]. Vidnovlyuvana energetika. 2013. No. 2. Pp. 49-53. [in Ukrainian].

9. Nakashidze L.V. Uluchshenie ekspluatacionnyh harakteristik sooruzhenij pri ispolzovanii energii alternativnyh istochnikov. [Improving the performance of facilities using energy from alternative sources]. International scientific journal «Alternativnaya energetika i ekologiya». 2014. № 23. Pp. 84-89. [in Russian].

10. Nakashidze L.V., Garbinec V.A. Formirovanie sostava sistemy energoobespecheniya, ispolzuyushej energiyu alternativnyh istochnikov. [Formation of the composition of the energy supply system using the energy of alternative sources].
Construction, materials science, mechanical engineering: collection of scientific papers. Series: Innovacionnye tehnologii zhiznennogo cikla obektov zhilishno-grazhdanskogo, promyshlennogo i transportnogo naznacheniya GVUZ «Pridnepr. gos. akademiya str-va i arhitektury». Dnipro. 2016. No. 87. Pp. 84-91. [in Russian].

11. Gabrinec V.O., Zarivnyak G.I., Mitrohov S.O., Nakashidze L.V. Patent for a utility model UA61489. Ukraine. IPC F24G 2/50. E04B 1/76. Energoaktivne ogorodzhennya [Energy-active fencing]. No. u201014333. Declared. 30.11.2010. Issued 25.07.2011. Bull. No.14. [in Ukrainian].

12. Nakashidze L.V., Shevchenko M.V., Gabrinec V.O. Patent for a utility model UA109070. Ukraine. IPC F24G 2/50. E04B 1/76. Energoaktivne ogorodzhennya [Energy-active fencing].Declared. 16.02.2016. Issued. 01.08.2016. Bull. No. 15. [in Ukrainian].

13. Protasevich A.M., Leshekevich A.M. Raschet temperaturnogo polya mnogoslojnyh ograzhdayushih konstrukcij $\mathrm{s}$ teploprovodnymi vklyucheniyami metodom konechnyh elementov. [Calculation of the temperature field of multilayer enclosing structures with heat-conducting inclusions by the finite element method]. Energy efficiency. Minsk. 2013. No. 10. Pp. 16-20. [in Russian].

14. Uproshennaya model solnechnogo nagreva poverhnostej. [Simplified model of solar surface heating]. Bogdan's blog. 2014. [Electronic resource].

URL: http://2nature.me/node/9321. [in Russian].

15. Fokin V.M. and others. Osnovy energosberezheniya $\mathrm{v}$ voprosah teploobmena. [Basics of energy saving in matters of heat transfer]. M. «Izdatelstvo Mashinostroenie-1». 2005. 192 p. [in Russian].
Стаття надійшла до редакції 03.08.20 Остаточна версія 16.03.21 